\title{
Preparation of Brushite Cements with Improved Properties by Adding Graphene Oxide [Corrigendum]
}

\author{
Nasrollahi N, Nourian Dehkordi A, Jamshidizad A,
} Chehelgerdi M. Int J Nanomed. 2019;14:3785-3797.

Figure 3 and the associated data were first published in 2017 by a separate group of authors, in the Journal of Bioactive and Compatible Polymers.

Permission to re-publish this figure was requested post-publication by authors Nasrollahi et al, after a reader brought this to our attention. The authors received permission from SAGE Publications to re-publish the figure on April 8, 2020.

The caption of Figure 3 on page 3789 should read:

Figure 3 Structural and morphological characteristics of synthesized GO: XRD (A) and AFM (B) of graphene.

Notes: Mohammadi S, Shafiei SS, Asadi-Eydivand M, Ardeshir M, Solati-Hashjin M. Journal of Bioactive and Compatible Polymers, 2017; 32 (3): 325-342, copyright (C) 2016 by The Author(s). Reprinted by Permission of SAGE Publications, Ltd. ${ }^{30}$

Abbreviations: XRD, x-ray diffraction; ARM, Atomic Force Microscopy.
The reference list should now include the following:

30. Mohammadi S, Shafiei SS, Asadi-Eydivand M, Ardeshir M, Solati-Hashjin M. Graphene oxide-enriched poly(E-caprolactone) electrospun nanocomposite scaffold for bone tissue engineering applications. $J$ Bioact Compat Polym. 2017; 32(3):325-342. doi:10.1177/0883 911516668666
International Journal of Nanomedicine

\section{Publish your work in this journal}

The International Journal of Nanomedicine is an international, peerreviewed journal focusing on the application of nanotechnology in diagnostics, therapeutics, and drug delivery systems throughout the biomedical field. This journal is indexed on PubMed Central, MedLine, CAS, SciSearch ${ }^{\circledR}$, Current Contents ${ }^{\mathbb{B}} /$ Clinical Medicine,
Journal Citation Reports/Science Edition, EMBase, Scopus and the Elsevier Bibliographic databases. The manuscript management system is completely online and includes a very quick and fair peer-review system, which is all easy to use. Visit http://www.dovepress.com/ testimonials.php to read real quotes from published authors. 